\title{
Benefits of Enhancing Nicotinamide Adenine Dinucleotide Levels in Damaged or Diseased Nerve Cells
}

\author{
Andrew A. Pieper ${ }^{1,2,3}$ And Steven L. McKnight ${ }^{4}$ \\ ${ }^{1}$ Harrington Discovery Institute, University Hospitals Cleveland Medical Center, \\ Cleveland, Ohio 44106, USA \\ ${ }^{2}$ Department of Psychiatry, Case Western Reserve University, Cleveland, Ohio 44106, USA \\ ${ }^{3}$ Geriatric Research Education and Clinical Centers, Louis Stokes Cleveland VAMC, \\ Cleveland, Ohio 44106, USA \\ ${ }^{4}$ Department of Biochemistry, University of Texas Southwestern Medical Center, \\ Dallas, Texas 75390, USA \\ Correspondence: steven.mcknight@utsouthwestern.edu; andrew.pieper@harringtondiscovery.org
}

\begin{abstract}
Three unbiased lines of research have commonly pointed to the benefits of enhanced levels of nicotinamide adenine dinucleotide $\left(\mathrm{NAD}^{+}\right)$to diseased or damaged neurons. Mice carrying a triplication of the gene encoding the culminating enzyme in $\mathrm{NAD}^{+}$salvage from nicotinamide, NMNAT, are protected from a variety of insults to axons. Protection from Wallerian degeneration of axons is also observed in flies and mice bearing inactivating mutations in the SARM1 gene. Functional studies of the SARM1 gene product have revealed the presence of an enzymatic activity directed toward the hydrolysis of NAD ${ }^{+}$. Finally, an unbiased drug screen performed in living mice led to the discovery of a neuroprotective chemical designated P7C3. Biochemical studies of the P7C3 chemical show that it can enhance recovery of $\mathrm{NAD}^{+}$from nicotinamide by activating NAMPT, the first enzyme in the salvage pathway. In combination, these three unrelated research endeavors offer evidence of the benefits of enhanced $\mathrm{NAD}^{+}$levels to damaged neurons.
\end{abstract}

This review covers three independent lines of investigation commonly concluding that the loss of nicotinamide adenine dinucleotide $\left(\mathrm{NAD}^{+}\right)$accompanies the demise of damaged or diseased axons. It is likewise argued that the same three lines of investigation predict that pathways facilitating either the preservation of $\mathrm{NAD}^{+}$or its enhanced biosynthesis may be protective of damaged or diseased axons. The first of these discoveries evolved from studies of a strain of mice that was found to be protected from Wallerian degeneration. The mutational event causative of this protective activity was traced to overexpression of a chimeric protein that includes the entire open reading frame encoding one of the three mammalian isoforms of the nicotinamide mononucleotide adenylyltransferase (NMNAT) enzyme. Enhanced expression of this enzyme facilitates preservation of $\mathrm{NAD}^{+}$levels in damaged or diseased axons (see Table 1). The second discovery relevant to the relationship between $\mathrm{NAD}^{+}$and axon health involved description of the fly gene designated $d$ Sarm. Inactivation of this gene in flies, or of the mouse ortholog Sarm 1, blocks NAD ${ }^{+}$decline in injured or diseased axons, thereby helping preserve axon integrity (see Table 1). The third discovery pertinent to these concepts entailed characterization of a synthetic chemical, designated P7C3, that modulates activity of the nicotinamide phosphoribosyltransferase (NAMPT) enzyme. Administration of the $\mathrm{P} 7 \mathrm{C} 3$ chemical to mice or rats elicits a protective effect on neuron integrity in several models of axon injury or disease (see Table 1). Each of these three discoveries re- sulted from serendipitous, unbiased research. That all three lines of investigation commonly identified preservation of $\mathrm{NAD}^{+}$levels as a means of protecting damaged or diseased axons offers credence to the concept that patients suffering deficits resulting from axon injury might benefit from agents that either preserve existing $\mathrm{NAD}^{+}$or facilitate enhanced $\mathrm{NAD}^{+}$synthesis.

\section{DISCOVERY OF WALLERIAN DEGENERATION SLOW $\left(\right.$ Wld $\left.^{\mathrm{S}}\right)$ MICE}

Wallerian degeneration is the process by which the portion of an axon degenerates distal to its site of injury. Early events in Wallerian degeneration include breakdown of the axon membrane and cytoskeleton, followed by myelin degeneration and macrophage infiltration (Beuche and Friede 1984). This process is named after Augustus Volney Waller, who discovered in 1850 that degenerating distal axons of transected frog glossopharyngeal nerves coalesced into droplets that could be visualized by cytological staining (Waller 1850). It was by use of this technique of visualizing nerve fiber degeneration that Lunn et al. (1989) made their serendipitous discovery of a line of mice characterized by abnormally delayed axon degeneration after sciatic nerve transection. Known as the C57BL/Ola strain and derived from a spontaneous mutation at Harlan-Olac in the United Kingdom, these mice were identified by their unusual ability to continue transmitting nerve impulses in

(C) 2018 Pieper and McKnight. This article is distributed under the terms of the Creative Commons Attribution-NonCommercial License, which permits reuse and redistribution, except for commercial purposes, provided that the original author and source are credited. 
Table 1. Efficacy of nicotinamide adenine dinucleotide-based therapies in preclinical models of the damaged or diseased nervous system

\begin{tabular}{|c|c|c|c|}
\hline & $W l d^{\mathrm{S}}$ & SARM1 & P7C3 \\
\hline \multicolumn{4}{|l|}{ Peripheral nerve disease } \\
\hline Po mouse & Protective & Not tested & Not tested \\
\hline Pmp22 rat & Protective & Not tested & Not tested \\
\hline \multicolumn{4}{|l|}{ Peripheral nerve toxicity } \\
\hline Paclitaxel-induced peripheral neuropathy & Protective & Protective & Protective \\
\hline Vincristine-induced peripheral neuropathy & Not tested & Protective & Not tested \\
\hline High fat diet/hyperglycemia-induced peripheral neuropathy & Not tested & Protective & Not tested \\
\hline \multicolumn{4}{|l|}{ Peripheral nerve injury } \\
\hline Sciatic nerve transection & Not tested & Protective & Not tested \\
\hline Sciatic nerve crush & Not tested & Not tested & Protective \\
\hline \multicolumn{4}{|l|}{ Spinal cord disease } \\
\hline pmn mouse & Protective & Not tested & Not tested \\
\hline \multicolumn{4}{|l|}{ Traumatic brain injury } \\
\hline Controlled cortical impact & Protective & Not tested & Protective \\
\hline Weight drop & Not tested & Protective & Not tested \\
\hline Blast-mediated injury & Protective & Not tested & Protective \\
\hline \multicolumn{4}{|l|}{ Stroke } \\
\hline Cerebral ischemia/reperfusion & Not tested & Not tested & Protective \\
\hline \multicolumn{4}{|l|}{ Parkinson's disease } \\
\hline 6-hydroxydopamine toxicity & Protective & Not tested & Protective \\
\hline MPTP toxicity & Protective & Not tested & Protective \\
\hline \multicolumn{4}{|l|}{ Alzheimer's disease } \\
\hline TgF344-AD rat & Not tested & Not tested & Protective \\
\hline
\end{tabular}

$W_{l} \mathrm{~S}$, SARM1, and P7C3 pathways converge on augmentation of neuronal NAD ${ }^{+}$levels and offer protection across common preclinical models of nervous system damage and disease.

the distal portion of severed axons for $2 \mathrm{wk}$ after transection, in contrast to only $2-3 \mathrm{~d}$ in control mice (Lunn et al. 1989; Perry et al. 1992). Otherwise, C57BL/Ola mice were indistinguishable from $\mathrm{C} 57 \mathrm{BL} / 6 \mathrm{~J}$ in appearance, behavior, and histocompatibility.

The resistance to Wallerian degeneration in C57BL/Ola mice was subsequently identified as intrinsic to nerve cells, and not related to Schwann cells (Glass et al. 1993) or circulating monocytes (Perry et al. 1990a). C57BL6/Ola mice also showed a protective effect in the central nervous system, with delayed retinal ganglion cell degeneration following optic nerve transection (Perry et al. 1991). A later observation that motor neuron cell death was similarly delayed in C57BL6/Ola mice after sciatic nerve axotomy confirmed a functional link between axon degeneration and neuronal cell death (Lapper et al. 1994).

These foundational observations prompted interest in discovering the genetic basis for resistance of C57BL6/ Ola mice to Wallerian degeneration. Crossing C57BL6/ Ola mice with BALB/c mice revealed that this property was inherited in single autosomal dominant fashion (Perry et al. 1990b). Three years later, the responsible gene was mapped to the distal end of mouse chromosome 4 at a locus designated $W l d$, which was syntenic to human chromosomal region 1p34-1p36 (Lyon et al. 1993). The symbol Wld $^{\mathrm{S}}$ (Wallerian degeneration slow) was assigned to the mutant allele, and C57/Ola mice were renamed $W_{l} d^{\mathrm{S}}$ mice. Over the next few years, the Perry laboratory progressively eliminated candidate genes in this region (Coleman et al. 1996) and ultimately identified an $85-\mathrm{kb}$ tandem triplication of the distal region of chromosome 4 that was unique to $\mathrm{C} 57 \mathrm{BL} / W l d^{\mathrm{S}}$ among 36 strains tested and thus was a strong candidate for the protective mutation (Coleman et al. 1998). This triplication was later found to be stably inherited across divergent breeding colonies of Wld $^{\mathrm{S}}$ mice (Mi et al. 2003).

In a relatively short time, Conforti et al. (2000) identified a chimeric gene within the $85-\mathrm{kb}$ tandem triplication region that was abundantly expressed in the nervous system and appeared responsible for resistance to Wallerian degeneration in $W l d^{\mathrm{S}}$ mice. This gene encoded an in-frame $42-\mathrm{kDa}$ fusion protein consisting of the amino-terminal 70 amino acids of the 1173 amino acid-long E4 ubiquitin ligase Ube $4 b$ protein, which was joined by an aspartic acid to the protein encoded by D4Colele. Given that only a very short region of $U b e 4 b$ was included, it was of no surprise that the fusion protein lacked ubiquitin ligase activity. In contrast, the entire coding region of D4Colele was fully included and quickly identified as being nearly identical to the recently cloned gene for human NMNAT (Emanuelli et al. 2001; Fernando et al. 2002), a metabolic enzyme that catalyzes $\mathrm{NAD}^{+}$synthesis from nicotinamide mononucleotide (NMN) and adenosine triphosphate (ATP) (Magni et al. 1999). Indeed, sequence alignment with human NMNAT showed that nucleotides 282-1140 of $W l d^{\mathrm{S}}$ contained the entire NMNAT open reading frame. Although a third gene, retinol binding protein 7 ( $R b p 7)$, was also positioned within the $85-\mathrm{kb}$ repeat unit, this gene was expressed predominantly in white adipose and mammary gland tissue, and found to be unrelated to the protective effect of $\mathrm{Wld}^{\mathrm{S}}$ (Conforti et al. 2000).

Within the next year, Mack et al. (2001) confirmed the critical role of NMNAT in the $85-\mathrm{kb}$ region by expressing the Ube $4 b / N m a t$ chimeric gene in transgenic mice. They observed NMNAT enzymatic activity and neuroprotective efficacy specified by the fusion protein in sensory and motor axons with respect to nerve conduction, synaptic transmission, vesicle recycling, and nerve terminal mor- 
phology. Furthermore, the protective effect was dose-dependently related to protein expression levels. They also showed that $W l d^{\mathrm{S}}$ mice display a fourfold increase in NMNAT enzyme activity in the brain compared to C57BL/6J mice (Mack et al. 2001). The following year, a novel human cDNA encoding a $34.4-\mathrm{kDa}$ protein with significant homology with the $31.9-\mathrm{kDa}$ NMNAT protein was also discovered. The new protein also had NAD biosynthetic activity and was named NMNAT2. The original NMNAT that had been identified as the human protein homologous to D4Colele was then renamed NMNAT1 (Raffaelli et al. 2002).

Multiple mechanisms have been proposed for how $W l d^{\mathrm{S}}$ mice are protected from Wallerian degeneration (Wishart et al. 2007; Wang and Barres 2012), including modification of cell cycle pathways (Wishart et al. 2008), optimization of mitochondrial function (Avery et al. 2012; Fang et al. 2012), control of expression of axonal receptors for glial-mediated engulfment of degenerating axons (Fainzilber and Twiss 2006; Hoopfer et al. 2006; MacDonald et al. 2006), and a hypothetical role of the Ube4b/NMNAT fusion protein as a molecular chaperone (Zhai et al. 2008). The most simple and likely correct explanation, however, is that $W l d^{\mathrm{S}}$ mice benefit from the maintenance of steadystate levels of $\mathrm{NAD}^{+}$through increased $\mathrm{NAD}^{+}$synthesis in damaged or diseased nerve cells (Wang et al. 2005; Coleman and Freeman 2010). The work by Araki et al. (2004) showed that NMNAT1 activity alone was sufficient to protect axons of explanted dorsal root ganglion neurons subjected to either traumatic transection or toxic exposure to vincristine, a chemotherapeutic drug that blocks tubulin assembly into microtubules. Subsequent generation of an additional $W l d^{\mathrm{S}}$ transgenic mammalian model — the $W l d^{\mathrm{S}}$ transgenic rat-further bolstered confidence in the utility of augmenting $\mathrm{NAD}^{+}$synthesis for neuroprotection, as these animals were resistant to Wallerian degeneration after sciatic nerve transection (Adalbert et al. 2005). More recently, in vitro studies have shown that extracellular NAD ${ }^{+}$ recapitulates the axonal protection seen in $W l d^{\mathrm{S}}$ neurons (Wang et al. 2015), presumably because of transport receptors that facilitate uptake of extracellular $\mathrm{NAD}^{+}$into nerve cells (Bruzzone et al. 2001).

Although initially found to be most highly abundant in the nucleus, the $W l d^{\mathrm{S}}$ fusion protein was later noted to also be enriched in mitochondria, cytosol, peroxisomes/lysosomes, endoplasmic reticulum, and axons (Yahata et al. 2009; Avery et al. 2012; Wang et al. 2015). Indeed, axonal localization of $W l d^{\mathrm{S}}$ appears to enable normally nuclear NMNAT1 to substitute for its axonal paralog NMNAT2, which is impaired in maintaining $\mathrm{NAD}^{+}$synthesis under conditions of axonal injury or stress. This insufficiency of NMNAT2 activity has been attributed to its short half-life and dependence of distal neurites on constant delivery of NMNAT2 from the soma (Berger et al. 2005; Gilley and Coleman 2010; Neukomm and Freeman 2014). Sasaki et al. (2016) have also reported that NMNAT2 inhibits the NAD hydrolase activity of SARM1 (described below), and that the NMNAT1 enzymatic domain of $W l d^{\mathrm{S}}$ somehow inhibits SARM1 after damage-induced loss of axonal NMNAT2.
In conclusion, although nuances of $W l d^{\mathrm{S}}$ function will undoubtedly require further study, it is clear that $\mathrm{NAD}^{+}$ synthesis plays a vital role in the resistance of mice to Wallerian degeneration. Because axonal loss is a prominent feature of neuropathies and other neurodegenerative diseases (Saxena and Caroni 2007), this discovery has prompted exploration of the potential benefits of augmenting $\mathrm{NAD}^{+}$synthesis in neurodegeneration. Indeed, $W l d^{\mathrm{S}}$ mice have been used extensively to study the physiology of reinnervation and peripheral nerve damage, and the applicability of $W l d^{\mathrm{S}}$ to peripheral and central nervous system degeneration has also been explored.

\section{$W^{\mathrm{S}}$ IN NEUROPROTECTION}

Because Wallerian degeneration is a prominent feature of injuries and disease in the peripheral nervous system, the resistance of $W l d^{\mathrm{S}}$ mice to peripheral neuropathy has been investigated in relevant animal models. For example, Samsam et al. (2003) crossed Wld $^{\mathrm{S}}$ mice with mice deficient in the peripheral myelin component $\mathrm{P} 0$, a model of human peripheral neuropathy, and observed delayed motor and sensory axon degradation. Several years later, Meyer zu Horste et al. (2011) crossed the Wld ${ }^{\mathrm{S}}$ rat with the Pmp22 rat, a transgenic model of Charcot-MarieTooth (CMT) disease type 1A, and observed that Wld $^{\mathrm{S}}$ reduced axon loss and behavioral deficits. With respect to the toxicity of anticancer chemicals, Wang et al. (2002) showed that $\mathrm{Wld}^{\mathrm{S}}$ mice were resistant to paclitaxel-mediated peripheral neuropathy.

In the central nervous system, axon loss occurs early in many disorders, including spinal cord injury (Zhang et al. 1996), amyotrophic lateral sclerosis (ALS) (Dal Canto and Gurney 1995; Fischer et al. 2004; Fischer and Glass 2007), Alzheimer's and Parkinson's diseases (Raff et al. 2002; Stokin et al. 2005; Kurowska et al. 2016), and traumatic brain injury (TBI) (Yin et al. 2014, 2016). Furthermore, the protection of neuronal cell bodies without preserving axons may be insufficient to prevent neurologic disease (Sagot et al. 1995; Houseweart and Cleveland 1999). Thus, there is considerable interest in finding ways to therapeutically protect axons in central nervous system injury and disease. As described above, the first application of $W l d^{\mathrm{S}}$ mice to the central nervous system was by Perry et al. (1991) through optic nerve transection experiments in which $W l d^{\mathrm{S}}$ mice showed delayed degeneration of retinal ganglion cells and their axons. Later work, however, showed that $W l d^{\mathrm{S}}$ rats were protected only from axon degeneration with no effect on retinal ganglion cell body deterioration after both optic nerve transection and a photocoagulation model of glaucoma (Beirowski et al. 2008). More recently, Williams et al. (2017) re-addressed this question in the DBA/2J (D2) mouse model of glaucoma, in which ocular hypertension leads to optic nerve degeneration $\sim 8-9$ mo of age, followed by retinal ganglion cell death. Crossing these mice with $\mathrm{Wld}^{\mathrm{S}}$ mice yielded animals showing increased retinal $\mathrm{NAD}^{+}$levels. The optic nerve axons and retinal ganglion cell bodies of these mice were protected from ocular hypertension. 
With respect to TBI, $W l d^{\mathrm{S}}$ mice display improved performance over wild-type mice in cognitive and motor behavior after controlled cortical impact injury (Fox and Faden 1998). More recently, Yin et al. (2016) reported that $W l d^{\mathrm{S}}$ mice are resistant to both retinal ganglion cell deterioration and axonal degeneration after blast-mediated TBI, and are protected from injury-induced cognitive and motor behavioral deficits. $W l d^{\mathrm{S}}$ has additionally been evaluated in models of Parkinson's disease because of the known degeneration of substantia nigra dopaminergic neurons. In 2004, Sajadi et al. tested susceptibility of $W l d^{\mathrm{S}}$ mice to the catecholaminergic toxin 6-hydroxydopamine (6OHDA) model of Parkinson's disease. Following injection of the toxin into the median forebrain bundle, $W l d^{\mathrm{S}}$ mice were partially protected from dopaminergic axon loss in the striatum. However, protection was restricted to portions of the axons distal to the site of toxin injection. As 6-OHDA is subject to retrograde transport from the site of injection back to the cell body, this selective regional protection presumably reflects unique neuronal processes governing primary and secondary injury after 6-OHDA exposure, with $W l d^{\mathrm{S}}$ being protective of the latter. A possible role of $W l d^{\mathrm{S}}$ for protection in Parkinson's disease was further examined with another chemical toxin, 1-methyl-4-phenyl-1,2,3,6-tetrahydropyridine (MPTP). Specifically, Hasbani and O'Malley (2006) reported that $W l d^{\mathrm{S}}$ mice were protected from nigrostriatal axon degeneration and striatal neurotransmitter loss in this model. However, as in the case of 6-OHDA (Sajadi et al. 2004), no protection from dopaminergic cell body death was observed in $W_{l} \mathrm{~S}^{\mathrm{S}}$ mice.

With respect to spinal cord disease, Ferri et al. (2003) evaluated efficacy of $W l d^{\mathrm{S}}$ in progressive motor neuronopathy ( $p m n$ ) mice, a model of human motor neuron disease. Here, $W l d^{\mathrm{S}}$ blocked axon degeneration and preserved associated motor function. Notably, previous work allowing for the controlled inhibition of apoptosis to protect motor neuron cell bodies without preserving axons in pmn mice did not modify disease progression (Sagot et al. 1995). Last, efficacy of $W l d^{\mathrm{S}}$ has been evaluated in animal models of ALS, based on a variety of mutations in the gene encoding $\mathrm{Cu} / \mathrm{Zn}$ superoxide dismutase 1 (SOD1) that have been identified in subsets of families with ALS. $W l d^{\mathrm{S}}$ has been evaluated in three of these models with marginal results. In $\mathrm{SOD}^{\mathrm{G} 37 \mathrm{R}}$ and $\mathrm{SOD}^{\mathrm{G} 85 \mathrm{R}}$ mouse models, $W l d^{\mathrm{S}}$ conferred no protection in disease onset, axon degeneration, synaptic integrity, or motor neuron death (Velde et al. 2004). In the SOD1 ${ }^{\mathrm{G} 93 \mathrm{~A}}$ mouse model, however, $W l d^{\mathrm{S}}$ modestly prolonged survival and delayed denervation at the neuromuscular junction, but had no effect on motor axon loss (Fischer et al. 2005).

\section{DISCOVERY OF SARM1}

Tight conservation of the axonal protective efficacy of $W l d^{\mathrm{S}}$ and NMNAT activity across species, including Drosophila melanogaster, prompted Marc Freeman to conduct a loss-of-function genetic screen in the fly with the goal of identifying other genes involved in controlling Wallerian degeneration (Osterloh et al. 2012). This unbiased screen revealed that mutational inactivation of dSarm (Drosophila sterile $\alpha /$ armadillo/Toll-interleukin 1 receptor [TIR] homology domain protein) suppressed Wallerian degeneration in a cell-autonomous manner for weeks after axotomy. Elimination of SARM1, the mammalian homolog of dSarm, in mice produced comparable long-term survival of damaged axons in vitro and in vivo. Freeman's discovery was later confirmed by Jeff Milbrandt, who identified SARM1 in a quantitative, image-based shRNA screen for genes required for axotomy-induced axon degeneration of explanted dorsal root ganglion cells (Gerdts et al. 2013). Millbrandt reported similarly reduced axon degeneration following sciatic nerve transection in SARM1 mutant mice, and showed that artificial activation of SARM1 in axons is both necessary and sufficient for Wallerian degeneration (Gerdts et al. 2016). Around this same time, others showed that SARM1 ablation in NMNAT2-deficient mice completely blocked axon degeneration and perinatal lethality (Gilley et al. 2015), indicating that these two proteins may function in opposition with respect to the physiology of damaged axons.

\section{MECHANISMS OF SARM1 ACTIVITY}

Prior to the aforementioned discoveries, SARM1 had been thought to function as an adaptor protein in innate immunity (Mink and Csizar 2005; O'Neill and Bowie 2007; Peng et al. 2010). Perplexingly, however, SARM1 was found to be unique among TIR-containing proteins in its selective enrichment in the nervous system (Kim et al. 2007). Indeed, before Freeman discovered the role of SARM1 in Wallerian degeneration, physiologic roles for SARM1 had been claimed in neural fate specification (Chuang and Bargmann 2005), dendritic arborization (Chen et al. 2011), and microglial activation (Szretter et al. 2009). To date, much of the mechanistic work to clarify the role of SARM1 in the nervous system has been conducted in the Milbrandt laboratory. They have shown that induced loss of mitochondrial membrane potential in cultured primary mouse sensory neurons induces a form of cell death pharmacologically distinct from apoptosis or necrosis. Without SARM1, the mitochondrial poison carbonyl cyanide m-chlorophenyl hydrazone (CCCP), an inhibitor of oxidative phosphorylation, elicits ATP depletion, excessive calcium influx, and accumulation of reactive oxygen species, yet fails to lead to axon degeneration or cell death (Summers et al. 2014). These observations, coupled with the finding that SARM1 elimination also protects neurons from prolonged exposure to reactive oxygen species (ROS), suggest that SARM1 acts downstream from ROS generation to induce cell death in times of oxidative stress. Milbrandt has thus proposed a form of programmed cell death in the peripheral nervous system downstream from ROS termed sarmoptosis (Summers et al. 2014).

Architecturally, SARM1 consists of 4 identifiable protein domains, including its MLS (mitochondrial localization signal), ARM (armadillo/HEAT motifs), SAM (sterile $\alpha$ motif), and TIR domains (Gerdts et al. 2016). A mutated variant of SARM1 lacking the amino-terminal ARM 
domain constitutively triggers axon degeneration, demonstrating that SARM1 may be auto-inhibited by its ARM domain (Gerdts et al. 2013). The SAM domain is required for SARM1 oligomerization and axon degeneration, and the TIR domain is also required for SARM1 to execute its role in axon degeneration (Gerdts et al. 2013; Summers et al. 2016). Indeed, dimerization of the TIR domain alone has been shown to induce rapid axon degeneration (Gerdts et al. 2015).

\section{THE TIR DOMAIN OF SARM1 SPECIFIES AN NAD ${ }^{+}$HYDROLASE ACTIVITY}

Numerous observations giving evidence that $\mathrm{NAD}^{+}$levels decline in damaged axons, complemented by the observation that forced expression of an activated form of SARM1 was capable of eliciting this same effect (Gerdts et al. 2015), prompted interest in how SARM1 might provide a link between $\mathrm{NAD}^{+}$loss and axon degeneration. In a surprising and exciting series of experiments, the Milbrandt laboratory found that the purified TIR domain of SARM1 itself specifies an NAD ${ }^{+}$hydrolase activity (Essuman et al. 2017). Through homology-based modeling of other proteins with related TIR domains, the Milbrandt group identified a glutamic acid residue essential for the TIR domain to hydrolyze $\mathrm{NAD}^{+}$(Essuman et al. 2017). The variants of SARM1 mutated at this single-amino-acid position fully eliminate the ability of SARM1 to execute its role in triggering Wallerian degeneration of axons. Most recently, the Milbrandt laboratory has made reference to TIR domains from prokaryotic organisms that also display $\mathrm{NAD}^{+}$hydrolase activity, suggesting a new class of TIRcontaining proteins as evolutionarily ancient metabolic regulatory enzymes (Essuman et al. 2018).

\section{SARM1 IN NEUROPROTECTION}

In studies of the peripheral nervous system, Geisler et al. (2016) exposed SARM1-deficient mice to a model of vincristine toxicity that mimics the neuropathy experienced by up to $80 \%$ of patients treated with vincristine (Casey et al. 1973; Verstappen et al. 2005), and is the main dose-limiting side effect of this form of chemotherapy (DeAngelis et al. 1991; Haim et al. 1994; Reinders-Messelink et al. 2000; Lavoie Smith et al. 2015). SARM1-deficient mice were protected in all parameters of vincristine toxicity. More recently, Turkiew et al. (2017) reported that SARM1-deficient mice are also protected from peripheral neuropathy induced by either paclitaxel or a high-fat diet.

In the central nervous system, minimal protection of SARM1-deficient mice was noted after optic nerve crush, and subsequent retinal ganglion cell death still occurred, as was observed for $W_{l d}$ mice (Fernandes et al. 2018). The Freeman laboratory has shown that SARM1-deficient mice display reduced axon degeneration and preserved neuronal function after exposure to TBI (Henninger et al. 2016). With respect to spinal cord disease, elimination of SARM1 was not protective in the SOD $1^{\mathrm{G} 93 \mathrm{~A}}$ mouse model of ALS (Peters et al. 2018).

\section{DISCOVERY OF THE P7C3 CLASS OF NEUROPROTECTIVE CHEMICALS}

Studies of two paralogous transcription factors designated neuronal PAS domain protein 1 (NPAS1) and neuronal PAS domain protein 3 (NPAS3) have given evidence for their role in the control of adult hippocampal neurogenesis in mice (Pieper et al. 2005; Stanco et al. 2014; Michaelson et al. 2017). Animals deficient in the NPAS 1 transcription factor display enhanced hippocampal neurogenesis. In contrast, animals missing the paralogous NPAS3 transcription factor display impaired hippocampal neurogenesis. Experimental evidence from the laboratory of Rusty Gage had likewise shown that adult neurogenesis in mice can be influenced by environment (Kempermann et al. 1997). Mice availed access to siblings and an enriched environment, such as a running wheel, display substantively enhanced hippocampal neurogenesis relative to mice deprived of these conditions. Recognizing from these various observations that the process of adult neurogenesis might be under dynamic control, we performed an unbiased, in vivo screen in search of proneurogenic chemicals (Pieper et al. 2010).

With help from Patrick Harran, a synthetic organic chemist in the Department of Biochemistry at University of Texas Southwestern Medical Center, a compound file consisting of 200,000 synthetic chemicals was trimmed down to 1000 individual molecules best representative of the diversity of the entire collection. These chemicals were combined into 100 pools of 10 individual compounds and administered directly into the brains of living mice. Continuous infusion for a period of $1 \mathrm{wk}$ was achieved via Alzet mini-pumps implanted beneath the skin of the backs of individual animals. To visualize neurogenesis, bromodeoxyuridine (BrdU) was coadministered along with each pool of compounds. After 1 wk animals were killed, allowing brain tissue to be sectioned and stained for BrdU incorporation into neurons localized to the subgranular zone of the dentate gyrus. The seventh of the 100 pools yielded a twofold enhanced level of hippocampal neurogenesis, and breakdown of this pool assigned proneurogenic activity to the third compound. This compound, designated pool seven compound three (P7C3) corresponded to an aminopropylcarbazole. Analysis of synthetic derivatives of the P7C3 chemical yielded the A20 variant, which showed reliably enhanced proneurogenic activity readily detected upon intraperitoneal or oral administration to either mice or rats (Pieper et al. 2010). It was subsequently shown that P7C3 achieved its proneurogenic effect by augmenting the survival of newborn hippocampal neurons without affecting their initial rate of proliferation.

\section{P7C3 COMPOUNDS FUNCTION AS NAMPT MODULATORS}

Subsequent to completion of the target-agnostic in vivo screen that led to the P7C3 chemical, coordinated efforts were initiated with the medicinal chemistry laboratory of Joseph Ready to probe its mechanism of action. A bio- 
logically active derivative of P7C3, known as P7C3-S326, was synthesized in the Ready laboratory to contain both a benzophenone for photo-cross-linking and an alkyne for CLICK chemistry (Wang et al. 2014). The observation that P7C3-A20, P7C3-S326, and other active derivatives of P7C3 (MacMillan et al. 2010; Naidoo et al. 2013, 2014), but not inactive variants, protected cultured U2OS cells from doxorubicin-induced toxicity provided a cell culture system for target discovery. The active enantiomer (-)-P7C3-S243 was protective from doxorubicin, whereas the inactive (+)-P7C3-S243 enantiomer was less protective. Incubation of P7C3-S326 in cultured U2OS cells showed that it could be photo-cross-linked to a $70-\mathrm{kDa}$ protein. Cross-linking was competed by coincubation with $30 \times$ excess of P7C3-A20. Roughly 150 P7C3 analogs were assayed for their ability to compete for photo-cross-linking of the 70-kDa protein by P7C3S326, and comparison of the observed pattern of competition to efficacy of the same compounds in protecting U2OS cells from doxorubicin toxicity yielded a significant correlation (Wang et al. 2014). Through cell fractionation, 2D gel electrophoresis, and mass spectrometry, it was determined that the $70-\mathrm{kDa}$ protein photo-crosslinked by P7C3-S326 was NAMPT, the rate-limiting enzyme in $\mathrm{NAD}^{+}$salvage by which cells sequentially convert nicotinamide into $\mathrm{NMN}$ and then $\mathrm{NAD}^{+}$(Preiss and Handler 1958).

Metabolite analysis of U2OS cells exposed to doxorubicin showed that toxin-mediated loss of $\mathrm{NAD}^{+}$was dose-dependently restored by cotreatment with P7C3A20. Correlation was noted between the ability of P7C3 variants to preserve $\mathrm{NAD}^{+}$levels and their ability to protect U2OS cells from doxorubicin-mediated toxicity (Wang et al. 2014). Administration of ${ }^{14} \mathrm{C}$-labeled nicotinamide to $\mathrm{U} 2 \mathrm{OS}$ cells pretreated with doxorubicin, and subsequent analysis by thin layer chromatography, revealed enhanced conversion of radiolabeled nicotinamide into $\mathrm{NAD}^{+}$ upon exposure to P7C3-A20. A triple-coupled assay was then developed to test the activities of P7C3 variants on a set of recombinant enzymes. The enzymes included NAMPT (which converts nicotinamide to NMN), NMNAT1 (which converts NMN to $\mathrm{NAD}^{+}$), and alcohol dehydrogenase (which converts $\mathrm{NAD}^{+}$to NADH). Flux of nicotinamde through this triply coupled enzyme assay was monitored by increase in fluorescence resulting from the production of NADH. By testing a large number of synthetic variants of P7C3 that had already been assayed for proneurogenic activity in mice, and for protection of U2OS cells from doxorubicin, a strong correlative relationship between this triply coupled enzyme assay and the two assays of P7C3 function in living animals or cells was revealed.

\section{P7C3 COMPOUNDS ARE NEUROPROTECTIVE}

Just as the role of $\mathrm{NAD}^{+}$in $W l d^{\mathrm{S}}$ and SARM1 neuroprotection was discovered via unbiased genetic approaches, the in vivo discovery of the P7C3 family of neuroprotective compounds was also unbiased. In combination, these three lines of evidence favor the concept of therapeutic utility of augmenting $\mathrm{NAD}^{+}$synthesis in damaged or diseased neurons. The neuroprotective efficacy of P7C3 compounds has been reported for central and peripheral forms of nerve cell injury or disease.

P7C3 treatment of neonatal rats subjected to sciatic nerve crush revealed protection of both motor and sensory nerve degeneration (Kemp et al. 2015). The potentially protective activity of $\mathrm{P} 7 \mathrm{C} 3$ in peripheral neurons has also been tested by the laboratory of William Clarke in a rat model of taxol-induced peripheral neuropathy. Robustly favorable measures of compound-mediated protection from both allodynia and nerve fiber degeneration were reported for this model of chemotherapy-induced peripheral neuropathy (LoCoco et al. 2017).

Beneficial effects of P7C3-mediated NAD-enhancement have been reported in the central nervous system for animal models of depression and anxiety (Walker et al. 2014; De Jesús-Cortés et al. 2016; Lee et al. 2016), TBI (Blaya et al. 2014), acute and chronic stroke (Loris et al. 2017a,b), and Alzheimer's disease (Choi et al. 2018; Voorhees et al. 2018). In addition to augmenting postnatal neurogenesis, P7C3 compounds also block axon degeneration and neuronal cell death in these models, with correlative protection from deficits in cognition and motor function. Also in TBI, Dutca et al. (2014) reported that (-)-P7C3-S243-mediated protection of retinal ganglion cell function subsequent to blast-mediated TBI. In both MPTP and 6-OHDA rodent models of Parkinson's disease, P7C3 compounds display a dose-dependent ability to preserve motor function and block degeneration of substantia nigra dopaminergic neurons and their axonal projections to the striatum (De Jesús-Cortés et al. 2012, 2015; Naidoo et al. 2014). Finally, P7C3-A20 has recently been found to promote the survival of young hippocampal neurons in nonhuman primates (Bauman et al. 2018). In the latter study, adult male rhesus monkeys receiving $38 \mathrm{wk}$ of daily, orally administered P7C3-A20 displayed sustained plasma exposure and elevated levels of postnatally born hippocampal neurons (Bauman et al. 2018).

\section{CONCLUSION}

We close this review with emphasis on the serendipity involved in the discoveries of $W l d^{\mathrm{S}}$, SARM1, and P7C3. The mouse that ended up encoding a triplicated version of the fusion protein linking a small bit of a ubiquitin ligase to the full open reading frame of NMNAT1 did not come from a comprehensive genetic screen, but instead emerged from careful analysis of a random mouse strain. It is remarkable that this one strain carried the aforementioned mutation, and perhaps even more remarkable that the Oxford scientists happened to evaluate the properties of this strain in the context of Wallerian degeneration. Studies pinpointing the product of dSARM1 in the pathway leading to degeneration of damaged axons were carefully conceived and meticulously executed. In this case, serendipity came in the discovery of a protein endowed with an un- 


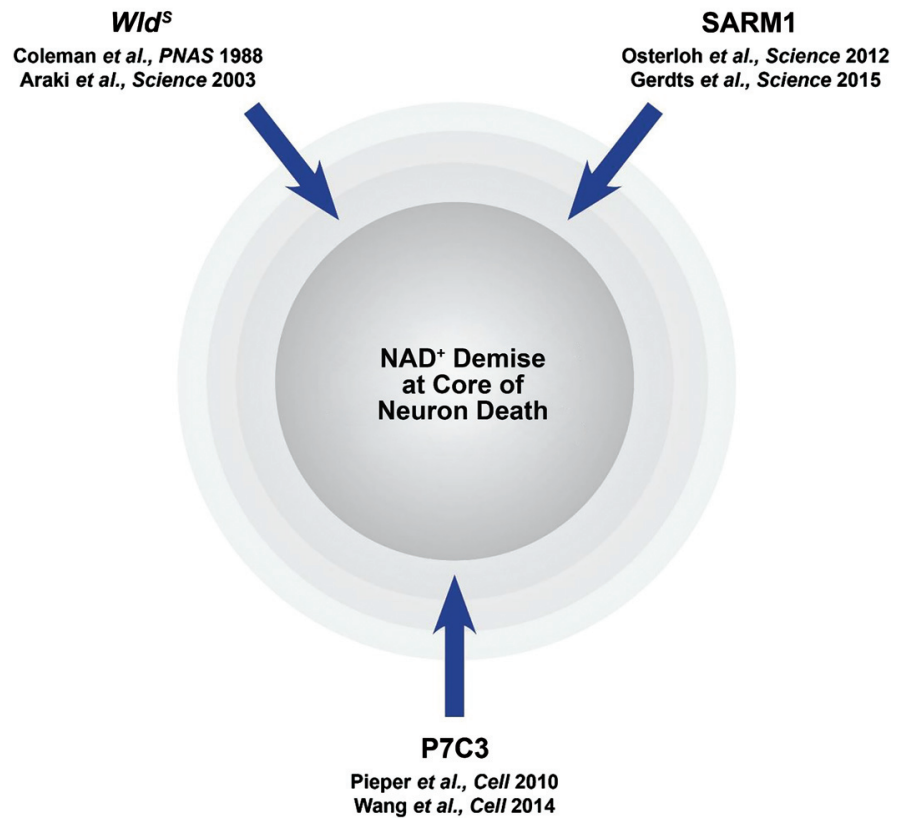

Figure 1. Three independent and unbiased discoveries have revealed neuroprotective efficacy of preservation or augmentation of $\mathrm{NAD}^{+}$levels in nerve cells. anticipated $\mathrm{NAD}^{+}$hydrolase activity essential for Wallerian degeneration. Finally, the drug screen leading to the discovery of the P7C3 chemical evaluated only 1000 synthetic chemicals. That this small collection included the neuroprotective, NAMPT-modulating aminopropylcarbazole chemical is undoubtedly serendipitous. Most remarkable of all is the apparent fact that all three approaches to the study of axon or neuron health commonly led to the same metabolite- $\mathrm{NAD}^{+}$. If these conclusions prove to be correct, they give evidence that the concept of $\mathrm{NAD}^{+}$ centrality to axon and neuron health is supported by a three-legged stool (see Fig. 1). It is hoped that the apparent stability of this foundation may properly point toward the utility of therapeutics that either enhance $\mathrm{NAD}^{+}$biosynthesis or prevent SARM1-mediated $\mathrm{NAD}^{+}$hydrolysis.

\section{ACKNOWLEDGMENTS}

A.A.P. is supported by the Brockman Medical Research Foundation, the Elizabeth Ring Mather \& William Gwinn Mather Fund, the S. Livingston Samuel Mather Trust, and the Department of Veterans Affairs Merit Review 1IO1BX002444 to A.A.P. A.A.P. and S.L.M. thank Sandi Estil, Joseph Ready, Gelin Wang, Ting Han, and many other coworkers who have been instrumental in the discovery and characterization of P7C3. Work on the discovery and characterization of the $\mathrm{P} 7 \mathrm{C} 3$ neuroprotective molecule was supported by a National Institutes of Health (NIH) Director's Pioneer Award and the provision of research funds to S.L.M. by an anonymous donor. The contents of this manuscript do not represent the views of the U.S. Department of Veterans Affairs or the U.S. Government.

\section{REFERENCES}

Adalbert R, Gillingwater TH, Haley JE, Bridge K, Beirowski B, Berek L, Wagner D, Grumme D, Thomson D, Celik A, et al. 2005. A rat model of slow Wallerian degeneration $\left(\right.$ Wld $\left.{ }^{\mathrm{S}}\right)$ with improved preservation of neuromuscular synapses. Eur J Neurosci 21: 271-277. doi:10.1111/j.1460-9568 2004.03833.x

Araki T, Sasaki Y, Milbrandt J. 2004. Increased nuclear NAD biosynthesis and SIRT1 activation prevent axonal degeneration. Science 305: 1010-1013. doi:10.1126/science .1098014

Avery MA, Rooney TM, Pandya JD, Wishart TM, Gillingwater TH, Geddes JW, Sullivan PG, Freeman MR. 2012. Wld $d^{\mathrm{S}}$ prevents axon degeneration through increased mitochondrial flux and enhanced mitochondrial $\mathrm{Ca}^{2+}$ buffering. Curr Biol 22: 596-600. doi:10.1016/j.cub.2012.02.043

Bauman MD, Schumann CM, Carlson EL, Taylor SL, VasquezRosa E, Cintron-Perez CJ, Shin M-K, Williams NS, Pieper AA. 2018. Neuroprotective efficacy of P7C3 compounds in primate hippocampus. Transl Psychiatry 8: 202-211. doi:10 .1038/s41398-018-0244-1

Beirowski B, Babetto E, Coleman MP, Martin KR. 2008. The $W l d^{\mathrm{S}}$ gene delays axonal but not somatic degeneration in a rat glaucoma model. Eur J Neurosci 28: 1166-1179. doi:10.1111/ j.1460-9568.2008.06426.x

Berger F, Lau C, Dahlman M, Ziegler M. 2005. Subcellular compartmentation and differential catalytic properties of the three human nicotinamide mononucleotide adenylyltransferase isoforms. J Biol Chem 280: 36334-36341. doi:10.1074/ jbc.M508660200

Beuche W, Friede RL. 1984. The role of non-resident cells in Wallerian degeneration. $J$ Neurocytol 13: 767-796. doi:10 $.1007 / \mathrm{BF} 01148493$

Blaya MO, Bramlett HM, Naidoo J, Pieper AA, Dietrich WD. 2014. Neuroprotective efficacy of a proneurogenic compound after traumatic brain injury. $J$ Neurotrauma 31: 476-486. doi:10.1089/neu.2013.3135

Bruzzone S, Guida L, Zocchi E, Franco L, De Flora A. 2001. Connexin 43 hemi channels mediate $\mathrm{Ca}^{2+}$-regulated transmembrane $\mathrm{NAD}^{+}$fluxes in intact cells. FASEB $J$ 15: 10-12. doi:10.1096/fj.00-0566fje 
Casey EB, Jellife AM, Le Quesne PM, Millett YL. 1973. Vincristine neuropathy. Clinical and electrophysiological observations. Brain 96: 69-86.

Chen CY, Lin CW, Chang CY, Jiang ST, Hsuch YP. 2011. Sarm1, a negative regulator of innate immunity, interacts with syndecan-2 and regulates neuronal morphology. J Cell Biol 193: 769-784. doi:10.1083/jcb.201008050

Choi SH, Bylykbashi E, Chatila ZK, Lee SW, Pulli B, Clemenson GD, Kim E, Rompala A, Oram ML, Asselin C, et al. 2018. Combined adult neurogenesis and BDNF mimic exercise effects on cognition in an Alzheimer's mouse model. Science 361: eaan8821. doi:10.1126/science.aan 8821

Chuang CF, Bargmann CI. 2005. A Toll-interleukin 1 repeat protein at the synapse specifies asymmetric odorant receptor expression via ASK1 MAPKKK signaling. Genes Dev 19: 270 281. doi:10.1101/gad.1276505

Coleman MP, Freeman MR. 2010. Wallerian degeneration, $W d^{\mathrm{S}}$, and nmnat. Annu Rev Neurosci 33: 245-267. doi:10.1146/ annurev-neuro-060909-153248

Coleman MP, Buckmaster EA, Ogunkolade BW, Tarlton A, Lyon MF, Brown MC, Perry VH. 1996. High-resolution mapping of the genes Kcnb3 and $L y 63$ on distal mouse chromosome 4. Mamm Genome 7: 552-553. doi:10.1007/s003359900287

Coleman MP, Conforti L, Buckmaster EA, Tarlton A, Ewing RM, Brown MC, Lyon MF, Perry VH. 1998. An 85-kb tandem triplication in the slow Wallerian degeneration $\left(W l d^{\mathrm{S}}\right)$ mouse. Proc Natl Acad Sci 95: 9985-9990. doi:10.1073/pnas.95.17.9985

Conforti L, Tarlton A, Macl TGA, Mi W, Buckmaster EA, Wagner D, Perr VH, Coleman MP. 2000. A Ufd2/D4Colele chimeric protein and overexpression of $R b p 7$ in the slow Wallerian degeneration $\left(\right.$ Wld $\left.^{\mathrm{S}}\right)$ mouse. Proc Natl Acad Sci 97: 11377-11382. doi:10.1073/pnas.97.21.11377

Dal Canto MC, Gurney ME. 1995. Neuropathological changes in two lines of mice carrying a transgene for mutant human $\mathrm{Cu}$, $\mathrm{Zn} \mathrm{SOD}$, and in mice overexpressing wild type human SOD: a model of familial amyotrophic lateral sclerosis (FALS). Brain Res 676: 25-40. doi:10.1016/0006-8993(95)00063-V

DeAngelis LM, Gnecco C, Taylor L, Warrell RP Jr. 1991. Evolution of neuropathy and myopathy during intensive vincristine/corticosteroid chemotherapy for non-Hodgkin's lymphoma. Cancer 67: 2241-2246. doi:10.1002/10970142(19910501)67:9<2241::AID-CNCR2820670905>3.0 .CO; $2-\mathrm{A}$

De Jesús-Cortés H, Xu P, Drawbridge J, Estill SJ, Huntingon PJ, Tran S, Britt JK, Tesla R, Morlock L, Naidoo J, et al. 2012. Neuroprotective efficacy of aminopropyl carbazoles in a mouse model of Parkinson disease. Proc Natl Acad Sci 109: 17010-17015. doi:10.1073/pnas.1213956109

De Jesús-Cortés H, Miller AD, Britt JK, DeMarco AJ, De Jesús-Cortés M, Steubing E, Naidoo J, Vázquez-Rosa E, Morlock L, Williams NS, et al. 2015. Protective efficacy of P7C3-S243 in the 6-hydroxydopamine model of Parkinson's disease. NPJ Parkinsons Dis 1: 15010. doi:10.1038/npjparkd .2015 .10

De Jesús-Cortes H, Rajadhyaksha AM, Pieper AA. 2016. Cacnalc: protecting young hippocampal neurons in the adult brain. Neurogenesis (Austin) 3: e1231160.

Dutca LM, Stasheff SF, Hedberg-Buenz A, Rudd DS, Batra N, Blodi FR, Yorek MS, Yin T, Shankar M, Herlein JA, et al. 2014. Early detection of subclinical visual damage after blastmediated TBI enables prevention of chronic visual deficit by treatment with P7C3-S243. Invest Ophthalmol Vis Sci 55: 8330-8341. doi:10.1167/iovs.14-15468

Emanuelli M, Carnevali F, Accucci F, Pierella F, Amici A, Raffaelli N, Magni G. 2001. Molecular cloning, chromosomal localization, tissue mRNA levels, bacterial expression, and enzymatic properties of human NMN adenylyltransferase. $J$ Biol Chem 276: 406-412. doi:10.1074/jbc.M008700200

Essuman K, Summers DW, Sasaki Y, Mao X, DiAntonio A, Milbrandt J. 2017. The SARM1 Toll/interleukin-1 receptor domain possesses intrinsic $\mathrm{NAD}^{+}$cleavage activity that promotes pathological axonal degeneration. Neuron 93: 13341343.e5. doi:10.1016/j.neuron.2017.02.022
Essuman K, Summers DW, Sasaki Y, Mao X, Yim AKY, DiAntonio A, Milbrandt J. 2018. TIR domain proteins are an ancient family of $\mathrm{NAD}^{+}$-consuming enzymes. Curr Biol 28: 421-430.e4. doi:10.1016/j.cub.2017.12.024

Fainzilber M, Twiss JL. 2006. Tracking in the $W l d^{\text {S }}$ - the hunting of the Sirt and the luring of the Draper. Neuron 50: 819-821. doi:10.1016/j.neuron.2006.05.023

Fang Y, Soares L, Teng X, Geary M, Bonimi NM. 2012. A novel Drosophila model of nerve injury reveals an essential role of Nmnat in maintaining axonal integrity. Curr Biol 22: 590595. doi:10.1016/j.cub.2012.01.065

Fernandes KA, Mitchell KL, Patel A, Marola OJ, Shrager P, Zack DJ, Libby RT, Welsbie DS. 2018. Role of SARM1 and DR6 in retinal ganglion cell axonal and somal degeneration following axonal injury. Exp Eye Res 171: 54-61. doi:10.1016/j.exer .2018 .03 .007

Fernando FS, Conforti L, Tosi S, Smith AD, Coleman MP. 2002. Human homologue of a gene mutated in the slow Wallerian degeneration (C57BL/Wld ${ }^{\mathrm{S}}$ ) mouse. Gene 284: 23-29. doi:10 .1016/S0378-1119(02)00394-3

Ferri A, Sanes JR, Coleman MP, Cunningham JM, Kato AC. 2003. Inhibiting axon degeneration and synapse loss attenuates apoptosis and disease progression in a mouse model of motoneuron disease. Curr Biol 13: 669-6.

Fischer LR, Glass JD. 2007. Axonal degeneration in motor neuron disease. Neurodegener Dis 4: 431-442. doi:10.1159/ 000107704

Fischer LR, Culver DG, Tennant P, Davis AA, Wang M, Castellano-Sanchez A, Khan J, Polak MA, Glass JD. 2004. Amyotrophic lateral sclerosis is a distal axonopathy: evidence in mice and man. Exp Neurol 185: 232-240. doi:10.1016/j .expneurol.2003.10.004

Fischer LR, Culver DG, Davis AA, Tennant P, Wang M, Coleman M, Asress S, Adalbert R, Alexander GM, Glass JD. 2005. The $W l d^{\mathrm{S}}$ gene modestly prolongs survival in the SOD1 ${ }^{\mathrm{G} 93 \mathrm{~A}}$ fALS mouse. Neurobiol Dis 19: 293-300. doi:10.1016/j.nbd.2005 .01 .008

Fox GB, Faden AI. 1998. Traumatic brain injury causes delayed motor and cognitive impairment in a mutant mouse strain known to exhibit delayed Wallerian degeneration. J Neurosci Res 53: 718-727. doi:10.1002/(SICI)1097-4547(19980915) 53:6<718::AID-JNR9>3.0.CO;2-8

Geisler S, Doan RA, Strickland A, Huang X, Milbrandt J, DiAntonio A. 2016. Prevention of vincristine-induced peripheral neuropathy by genetic deletion of SARM1 in mice. Brain 139: 3092-3108. doi:10.1093/brain/aww251

Gerdts J, Summers DW, Sasaki Y, DiAntonio A, Milbrandt J. 2013. Sarm1-mediated axon degeneration requires both SAM and TIR interactions. J Neurosci 33: 13569-13580. doi:10.1523/JNEUROSCI.1197-13.2013

Gerdts J, Brace EJ, Sasaki Y, DiAntonio A, Milbrandt J. 2015. SARM1 activation triggers axon degeneration locally via $\mathrm{NAD}^{+}$destruction. Science 348: 453-457. doi:10.1126/sci ence. 1258366

Gerdts J, Summers DW, Milbrandt J, DiAntonio A. 2016. Axon self-destruction: new links among SARM1, MAPKs, and NAD ${ }^{+}$metabolism. Neuron 89: 449-460. doi:10.1016/j .neuron.2015.12.023

Gilley J, Coleman MP. 2010. Endogenous Nmnat2 is an essential survival factor for maintenance of healthy axons. PLoS Biol 8: e1000300. doi:10.1371/journal.pbio. 1000300

Gilley J, Orsomando G, Nascimento-Ferreira I, Coleman MP. 2015. Absence of SARM1 rescues development and survival of NMNAT2-deficient axons. Cell Rep 10: 1974-1981. doi:10 $.1016 /$ j.celrep.2015.02.060

Glass JD, Brushart TM, George EB, Griffin JW. 1993. Prolonged survival of transected nerve fibres in C57BL/Ola mice is an intrinsic characteristic of the axon. J Neurocytol 22: 311-321.

Haim N, Epelbaum R, Ben-Shahar M, Yarnitsky D, Simri W, Robinson E. 1994. Full dose vincristine (without 2-mg dose limit) in the treatment of lymphomas. Cancer 73: 2515-2519. doi:10.1002/1097-0142(19940515)73:10<2515::AID-CNCR 2820731011>3.0.CO;2-G 
Hasbani DM, O’Malley KL. 2006. Wld ${ }^{\mathrm{S}}$ mice are protected against the Parkinsonian mimetic MPTP. Exp Neurol 202: 93-99. doi:10.1016/j.expneurol.2006.05.017

Henninger N, Bouley J, Sikoglu EM, An J, Moore CM, King JA, Bowser R, Freeman MR, Brown RH Jr. 2016. Attenuated traumatic axonal injury and improved functional outcome after traumatic brain injury in mice lacking Sarm1. Brain 139: 1094-1105. doi:10.1093/brain/aww001

Hoopfer ED, McLaughlin T, Watts RJ, Schuldiner O, O’Leary DDM, Luo L. 2006. $W l d^{\mathrm{S}}$ protection distinguishes axon degeneration following injury from naturally occurring developmental pruning. Neuron 50: 883-895. doi:10.1016/j.neuron .2006 .05 .013

Houseweart MK, Cleveland DW. 1999. Bcl-2 overexpression does not protect neurons from mutant neurofilament-mediated motor neuron degeneration. J Neurosci 19: 6446-6456. doi:10 .1523/JNEUROSCI.19-15-06446.1999

Kemp SWP, Szynkaruk M, Stanoulis KN, Wood MD, Liu EH, Willand MP, Morlock L, Naidoo J, Willams NS, Ready JM, et al. 2015. Pharmacologic rescue of motor and sensory function by the neuroprotective compound $\mathrm{P} 7 \mathrm{C} 3$ following neonatal nerve injury. Neuroscience 284: 202-216. doi:10.1016/j .neuroscience.2014.10.005

Kempermann G, Kuhn HG, Gage FH. 1997. More hippocampal neurons in adult mice living in an enriched environment. $\mathrm{Na}$ ture 386: 493-495. doi: $10.1038 / 386493 \mathrm{a} 0$

Kim Y, Zhou P, Qian L, Chuang JZ, Lee J, Li C, Iadecola C, Nathan C, Ding A. 2007. MyD88-5 links mitochondria, microtubules, and JNK3 in neurons and regulates neuronal survival. J Exp Med 204: 2063-2074. doi:10.1084/jem.20070868

Kurowska Z, Kordower JH, Stoessl AJ, Burke RE, Brunden P, Yue Z, Brady ST, Milbrandt J, Trapp BD, Sherer TB, et al. 2016. Is axonal degeneration a key early event in Parkinson's disease? J Parkinsons Dis 6: 703-707. doi:10.3233/JPD-160881

Lapper SR, Brown MC, Perry VH. 1994. Motor neuron cell death induced by axotomy in neonatal mice occurs more slowly in a mutant strain in which Wallerian degeneration is very slow. Eur J Neurosci 6: 473-477. doi:10.1111/j.1460-9568.1994 .tb00289.x

Lavoie Smith EM, Li L, Chiang C, Thomas K, Hutchinson RJ, Wells EM, Ho RH, Skiles J, Chakraborty A, Bridges CM, et al 2015. Patterns and severity of vincristine-induced peripheral neuropathy in children with acute lymphoblastic leukemia. $J$ Peripher Nerv Syst 20: 37-46.

Lee AS, De Jesús-Cortés H, Kabir ZD, Knobbe W, Orr M, Burgdorf C, Huntington P, McDaniel L, Britt JK, Hoffmann F, et al. 2016. The neuropsychiatric disease-associated gene cacnalc mediates survival of young hippocampal neurons. eNeuro 3: ENEURO.0006-16.2016. doi:10.1523/ENEURO.0006-16 .2016

LoCoco PM, Risinger AL, Smith HR, Chavera TS, Berg KA, Clarke WP. 2017. Pharmacological augmentation of nicotinamide phosphoribosyltransferase (NAMPT) protects against paclitaxel-induced peripheral neuropathy. eLife 6: e29626. doi:10.7554/eLife. 29626

Loris ZB, Pieper AA, Dietrich WD. 2017a. The neuroprotective compound $\mathrm{P} 7 \mathrm{C} 3-\mathrm{A} 20$ promotes neurogenesis and improves cognitive function after ischemic stroke. Exp Neurol 290: 63-73. doi:10.1016/j.expneurol.2017.01.006

Loris ZB, Hynton JR, Pieper AA, Dietrich WD. 2017b. Beneficial effects of delayed P7C3-A20 treatment after transient MCAO in rats. Transl Stroke Res 9: 146-156. doi:10.1007/ s12975-017-0565-Z

Lunn ER, Perry VH, Brown MC, Rosen H, Gordon S. 1989. Absence of Wallerian degeneration does not hinder regeneration in peripheral nerve. Eur J Neurosci 1: 27-33. doi:10.1111/ j.1460-9568.1989.tb00771.x

Lyon MF, Ogunkolade BW, Brown MC, Atherton DJ, Perry VH. 1993. A gene affecting Wallerian nerve degeneration maps distally on mouse chromosome 4. Proc Natl Acad Sci 90: 9717-9720. doi:10.1073/pnas.90.20.9717

MacDonald JM, Beach MG, Porpiglia W, Sheehan AE, Watts RJ, Freeman MR. 2006. The Drosophila cell corpse engulfment receptor Draper mediates glial clearance of severed axons. Neuron 50: 869-881. doi:10.1016/j.neuron.2006.04.028

MacMillan KS, Naidoo J, Liang J, Melito L, Williams NS, Morlock L, Huntington P, Estill SJ, Longgood J, Becker GL, et al. 2010. Development of proneurogenic, neuroprotective small molecules. JACS 133: 1428-1437. doi:10.1021/ ja108211m

Mack TGA, Reiner M, Beirowski B, Mi W, Emanuelli M, Wagner D, Thomson D, Gillingwater T, Court F, Conforti L, et al. 2001. Wallerian degeneration of injured axons and synapses is delayed by a Ube4b/Nmnat chimeric gene. Nat Neurosci 12: 1199-1206. doi:10.1038/nn770

Magni G, Amici A, Emanuelli M, Raffaelli N, Ruggieri S. 1999. Enzymology of $\mathrm{NAD}^{+}$synthesis. Adv Enzymol Relat Areas Mol Biol 73: 135-182.

Meyer zu Horste G, Miesbach TA, Muller JI, Fledrich R, Stassart RM, Kieseier BC, Coleman MP, Sereda MW. 2011. The $W^{S} d^{\mathrm{S}}$ transgene reduces axon loss in a Charcot-Marie-Tooth disease $1 \mathrm{~A}$ rat model and nicotinamide delays post-traumatic axonal degeneration. Neurobiol Dis 42: 1-8. doi:10.1016/j.nbd.2010 .12 .006

Mi W, Glass JD, Coleman MP. 2003. Stable inheritance of an 85$\mathrm{kb}$ triplication in $\mathrm{C} 57 \mathrm{BL} /$ Wld $^{\mathrm{S}}$ mice. Mutat Res 526: 33-37. doi:10.1016/S0027-5107(03)00011-3

Michaelson JJ, Shin MK, Koh JY, Brueggeman L, Zhang A, Katzman A, McDaniel L, Fang M, Pufall M, Pieper AA. 2017. Neuronal PAS domain proteins 1 and 3 are master regulators of neuropsychiatric risk genes. Biol Psych 82: 213 223.

Mink M, Csizar K. 2005. SARM1: a candidate gene in the onset of hereditary infectious/inflammatory diseases. Clin Immunol 115: 333-334. doi:10.1016/j.clim.2005.03.002

Naidoo J, Bembem CJ, Allwein SR, Liang J, Pieper AA, Ready JM. 2013. Development of a scalable synthesis of P7C3-A20, a potent neuroprotective agent. Tetrahedron Lett 54: 44294431. doi:10.1016/j.tetlet.2013.06.024

Naidoo J, De Jesus-Cortes H, Huntington P, Estill S, Morlock LK, Starwalt R, Mangano TJ, Williams NS, Pieper AA, Ready JM. 2014. Discovery of a neuroprotective chemical, $(S)-N-(3-$ (3,6-dibromo-9H-carbazol-9-yl)-2-fluoropropyl)-6-methoxypyridin-2-amine [(-)-P7C3-S243], with improved druglike properties. J Med Chem 57: 3746-3754. doi:10.1021/ jm401919s

Neukomm LJ, Freeman MR. 2014. Diverse cellular and molecular modes of axon degeneration. Trends in Cell Biol 24: 512 523. doi:10.1016/j.tcb.2014.04.003

O'Neill LA, Bowie AG. 2007. The family of five: TIR-domaincontaining adaptors in Toll-like receptor signaling. Nat Rev Immunol 7: 353-364. doi:10.1038/nri2079

Osterloh JM, Yang J, Rooney TM, Fox AN, Adalbert R, Powell EH, Sheehan AE, Avery MA, Hacket R, Logan MA, et al. 2012. dSarm/Sarm1 is required for activation of an injuryinduced axon death pathway. Science 337: 481-484. doi:10 $.1126 /$ science. 1223899

Peng J, Yuan Q, Lin B, Panneerselvam P, Wang X, Luan XL, Lim SK, Leung BP, Ho B, Ding JL. 2010. SARM inhibits both TRIF- and MyD88-mediated AP-1 activation. Eur J Immunol 40: 1738-1747. doi:10.1002/eji.200940034

Perry VH, Brown MC, Lunn ER, Tree P, Gordon S. 1990a. Evidence that very slow Wallerian degeneration in C57BL/ Ola mice is an intrinsic property of the peripheral nerve. Eur J Neurosci 2: 802-808. doi:10.1111/j.1460-9568.1990 .tb00472.x

Perry VH, Lunn ER, Brown MC, Cahusac S, Gordon S. 1990b. Evidence that the rate of Wallerian degeneration is controlled by a single autosomal dominant gene. Eur J Neurosci 2: 408413. doi:10.1111/j.1460-9568.1990.tb00433.x

Perry VH, Brown MC, Lunn ER. 1991. Very slow retrograde and Wallerian degeneration in the CNS of C57BL/Ola mice. Eur J Neurosci 3: 102-105. doi:10.1111/j.1460-9568.1991 .tb00815.x

Perry VH, Brown MC, Tsao JW. 1992. The effectiveness of the gene which slows the rate of Wallerian degeneration in C57BL/ 
Ola mice declines with age. Eur J Neurosci 4: 1000-1002. doi:10.1111/j.1460-9568.1992.tb00126.x

Peters OM, Lewis EA, Osterloh JM, Weiss A, Salameh JS, Mettervile J, Brown RH, Freeman MR. 2018. Loss of Sarm1 does not suppress motor neuron degeneration in the SOD1 1 93A mouse model of amyotrophic lateral sclerosis. Hum Mol Genet 27: 3761-3771. doi:10.1093/hmg/ddy260

Pieper AA, Wu X, Han TW, Estill SJ, Dang Q, Wu LC, ReeceFincanon S, Dudley CA, Richardson JA, Brat DJ, et al. 2005. The neuronal PAS domain protein 3 transcription factor controls FGF-mediated adult hippocampal neurogenesis in mice. Proc Natl Acad Sci 102: 14052-14057. doi:10.1073/ pnas.0506713102

Pieper AA, Xie S, Capota E, Estill SJ, Zhong J, Long JM, Becker GL, Huntington P, Goldman SE, Shen S-H, et al. 2010. Discovery of a proneurogenic, neuroprotective chemical. Cell 142: 39-51. doi:10.1016/j.cell.2010.06.018

Preiss J, Handler P. 1958. Biosynthesis of diphosphopyridine nucleotide. I. Identification of intermediates. $J$ Biol Chem 233: 486-492.

Raff MC, Whitmore AV, Finn JT. 2002. Axonal self-destruction and neurodegeneration. Science 296: 868-871. doi:10.1126/ science. 1068613

Raffaelli N, Sorci L, Amici A, Emanuelli M, Mazzola F, Magni G. 2002. Identification of a novel human nicotinamide mononucleotide adenylyltransferase. Biochem Biophys Res Commun 297: 835-840. doi:10.1016/S0006-291X(02) 02285-4

Reinders-Messelink HA, van Weerden TW, Fock JM, Gidding CEM, Vingerhoets HM, Schoemaker MM, Goeken LNH, Bokkerink JPM, Kamps WA. 2000. Mild axonal neuropathy of children during treatment for acute lymphoblastic leukaemia. Eur J Paediatr Neurol 4: 225-233. doi:10.1053/ejpn .1999 .0310

Sagot Y, Dubois-Dauphin M, Tan SA, de Bilbao F, Aebischer P, Martinou JC, Kato AC. 1995. Bcl-2 overexpression prevents motoneuron cell body loss but not axonal degeneration in a mouse model of a neurodegenerative disease. J Neurosci 15: 7727-7733. doi:10.1523/JNEUROSCI.15-11-07727 .1995

Sajadi A, Schneider BL, Aebischer P. 2004. $W l d^{\mathrm{S}}$-mediated protection of dopaminergic fibers in an animal model of Parkinson disease. Curr Biol 14: 326-330. doi:10.1016/j.cub.2004 .01 .053

Samsam M, Mi W, Wessig C, Zielasek J, Toyka KV, Coleman MP, Martini R. 2003. The $W l d^{\mathrm{S}}$ mutation delays robust loss of motor and sensory axons in a genetic model for myelin-related neuropathy. J Neurosci 23: 2833-2839. doi:10.1523/JNEUR OSCI.23-07-02833.2003

Sasaki Y, Nakagawa T, Mao X, DiAntonio A, Milbrandt J. 2016. NMNAT1 inhibits axon degeneration via blockade of SARM1-mediated NAD+ depletion. elife 5: e19749. doi:10 .7554/eLife. 19749

Saxena S, Caroni P. 2007. Mechanisms of axon degeneration: From development to disease. Prog Neurobiol 83: 174-191. doi:10.1016/j.pneurobio.2007.07.007

Stanco A, Pla R, Vogt D, Chen Y, Mandal S, Walker J, Hunt RF, Lindtner S, Erdman CA, Pieper AA, et al. 2014. NPAS1 represses the generation of specific subtypes of cortical interneurons. Neuron 84: 940-953. doi:10.1016/j.neuron.2014 .10 .040

Stokin GB, Lillo C, Falzone TL, Brusch RG, Rockenstein E, Mount SL, Raman R, Davies P, Masliah E, Williams DS, et al. 2005. Axonopathy and transport deficits early in the pathogenesis of Alzheimer's disease. Science 307: 12821288. doi:10.1126/science. 1105681

Summers DW, DiAntonio A, Millbrandt J. 2014. Mitochondrial dysfunction induces Sarm1-dependent cell death in sensory neurons. J Neurosci 34: 9338-9350. doi:10.1523/JNEURO SCI.0877-14.2014

Summers DW, Gibson DA, DiAntonio A, Milbrandt J. 2016. SARM1-specific motifs in the TIR domain enable NAD loss and regulate injury-induced SARM1 activation.
Proc Natl Acad Sci 113: E6271-E6280. doi:10.1073/pnas .1601506113

Szretter KJ, Samuel MA, Gilfillan S, Fuchs A, Colonna M, Diamond MS. 2009. The immune adaptor molecule SARM modulates tumor necrosis factor alpha production and microglia activation in the brainstem and restricts West Nile Virus pathogenesis. J Virol 83: 9329-9338. doi:10.1128/JVI.00 836-09

Turkiew E, Falconer D, Reed N, Hoke A. 2017. Deletion of Sarm1 is neuroprotective in two models of peripheral neuropathy. J Peripher Nerv Syst 22: 162-171. doi:10.1111/jns.12219

Velde CV, Garcia ML, Yin X, Trapp BD, Cleveland DW. 2004. The neuroprotective factor $W l d^{\mathrm{S}}$ does not attenuate mutant $\mathrm{SOD}_{1}$-mediated motor neuron disease. Neuromolecular Med 5: 193-203. doi:10.1385/NMM:5:3:193

Verstappen CCP, Koeppen S, Heimans JJ, Huijgens PC, Scheulen ME, Strumberg D, Kiburg B, Postma TJ. 2005. Dose-related vincristine-induced peripheral neuropathy with unexpected off-therapy worsening. Neurology 64: 1076-1077. doi:10 .1212/01.WNL.0000154642.45474.28

Voorhees JR, Remy MT, Cintrón-Pérez CJ, El Rassi E, Khan MZ, Dutca LM, Yin TC, McDaniel LN, Williams NS, Brat DJ, et al. 2018. (-)-P7C3-S243 protects a rat model of Alzheimer's disease from neuropsychiatric deficits and neurodegeneration without altering amyloid deposition or reactive glia. Biol Psychiatry 84: 488-498. doi:10.1016/j.biopsych .2017.10.023

Walker AK, Rivera PD, Wang Q, Chuang J-C, Tran S, OsborneLawrence S, Estill SJ, Starwalt R, Huntington P, Morlock L, et al. 2014. The P7C3 class of neuroprotective compounds exerts antidepressant efficacy in mice by increasing hippocampal neurogenesis. Mol Psychiatry 4: 500-508. doi:10.1038/mp .2014 .34

Waller A. 1850. XX. Experiments on the section of the glossopharyngeal and hypoglossal nerves of the frog, and observations of the alterations produced thereby in the structure of their primitive fibres. Phil Trans Roy Soc London 140: 423429. doi:10.1098/rstl.1850.0021

Wang JT, Barres BA. 2012. Axon degeneration: where the $W l d^{\mathrm{S}}$ things are. Curr Biol 22: R221-R223. doi:10.1016/j.cub.2012 .02 .056

Wang MS, Davis AA, Culver DG, Glass JD. 2002. $W l d^{\mathrm{S}}$ mice are resistant to paclitaxel (taxol) neuropathy. Ann Neurol 52: 442447. doi:10.1002/ana.10300

Wang J, Zhai Q, Chen Y, Lin E, Gu W, McBurney MW, He Z. 2005. A local mechanism mediates NAD-dependent protection of axon degeneration. J Cell Biol 170: 349-355. doi:10 $.1083 /$ jcb.200504028

Wang G, Han T, Nijhawan D, Theodoropoulos P, Naidoo J, Yadavalli S, Mirzaei H, Pieper AA, Ready JM, McKnight SL. 2014. P7C3 neuroprotective chemicals function by activating the rate-limiting enzyme in NAD salvage. Cell 158: 1324-1334. doi:10.1016/j.cell.2014.07.040

Wang JT, Medress ZA, Vargas ME, Barres BA. 2015. Local axonal protection by $W l d^{\mathrm{S}}$ as revealed by conditional regulation of protein stability. Proc Natl Acad Sci 112: 1009310100. doi:10.1073/pnas. 1508337112

Williams PA, Harder JM, Foxworth NE, Cardozo BH, Cochran KE, John SWM. 2017. Nicotinamide and $W l d^{\mathrm{S}}$ act together to prevent neurodegeneration in glaucoma. Front Neurosci 11: 232. doi: $10.3389 /$ fnins.2017.00232

Wishart TM, Paterson JM, Short DM, Meredith S, Robertson KA, Sutherland C, Cousin MA, Dutia MB, Gillingwater TH. 2007. Differential proteomics analysis of synaptic proteins identifies potential cellular targets and protein mediators of synaptic neuroprotection conferred by the slow Wallerian degeneration $\left(W_{l} d^{\mathrm{S}}\right)$ gene. Mol Cell Proteomics 6: 13181330. doi:10.1074/mcp.M600457-MCP200

Wishart TM, Pemberton HN, James SR, McCabe CJ, Gillingwater TH. 2008. Modified cell cycle status in a mouse model of altered neuronal vulnerability (slow Wallerian degeneration; Wld $^{\mathrm{S}}$ ). Genome Biol 9: R101. doi:10.1186/gb-2008-96-r101 
Yahata N, Yuasa S, Araki T. 2009. Nictotinamide mononucleotide adenylyltransferase expression in mitochondrial matrix delays Wallerian degeneration. J Neurosci 29: 6276-6284. doi:10.1523/JNEUROSCI.4304-08.2009

Yin TC, Britt JK, De Jesús-Cortés H, Lu Y, Genova RM, Khan MZ, Voorhees JR, Shao J, Katzman AC, Huntington P, et al. 2014. P7C3 neuroprotective chemicals block axonal degeneration and preserve function after traumatic brain injury. Cell Rep 8: 1731-1740. doi:10.1016/j.celrep.2014.08.030

Yin TC, Voorhees JR, Genova RM, Davis KC, Madison AM, Britt JK, Cintrón-Pérez CJ, McDaniel L, Harper MM, Pieper AA. 2016. Acute axonal degeneration drives development of cognitive, motor, and visual deficits after blast-mediated trau- matic brain injury in mice. eNeuro 3: ENEURO.022016.2016. doi:10.1523/ENEURO.0220-16.2016

Zhai RG, Zhang F, Hiesinger PR, Cao Y, Hauter CM, Bellen HJ. 2008. NAD synthase NMNAT acts as a chaperone to protect against neurodegeneration. Nature 452: 887-891. doi:10 $.1038 /$ nature 06721

Zhang Z, Fujiki M, Guth L, Steward O. 1996. Genetic influences on cellular reactions to spinal cord injury: a woundhealing response present in normal mice is impaired in mice carrying a mutation $\left(W l d^{\mathrm{S}}\right)$ that causes delayed Wallerian degeneration. J Comp Neurol 371: 485-495. doi:10.1002/ (SICI)1096-9861(19960729)371:3<485::AID-CNE10>3.0 .CO;2-I 


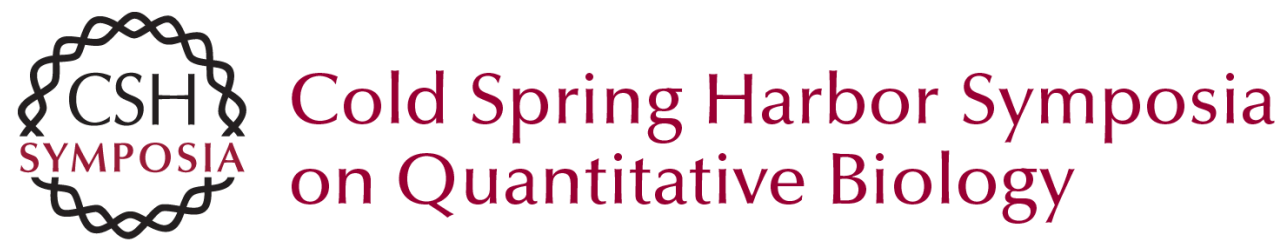

\section{Benefits of Enhancing Nicotinamide Adenine Dinucleotide Levels in Damaged or Diseased Nerve Cells}

Andrew A. Pieper and Steven L. McKnight

Cold Spring Harb Symp Quant Biol 2018 83: 207-217 originally published online February 20, 2019

Access the most recent version at doi:10.1101/sqb.2018.83.037622

References This article cites 113 articles, 31 of which can be accessed free at: http://symposium.cshlp.org/content/83/207.full.html\#ref-list-1

Creative This article is distributed under the terms of the

Commons http://creativecommons.org/licenses/by-nc/4.0/, which permits reuse and

License redistribution, except for commercial purposes, provided that the original author and source are credited.

Email Alerting Receive free email alerts when new articles cite this article - sign up in Service the box at the top right corner of the article or click here. 